\title{
Enzymatic kinetic method for determination of propranolol hydrochloride in pharmaceuticals based on its inhibitory effect on cholinesterase
}

\author{
Vesna P. Stankov-Jovanović ${ }^{1}$, Violeta D. Mitić ${ }^{1}$ Marija D. Ilić ${ }^{1}$, Ljuba M. Mandić ${ }^{2}$, \\ Snežana D. Nikolić-Mandić ${ }^{2}$ \\ ${ }^{1}$ University of Niš, Faculty of Science and Mathematics, Department of Chemistry, Niš, Serbia \\ ${ }^{2}$ University of Belgrade, Faculty of Chemistry, Belgrade, Serbia
}

\begin{abstract}
Propranolol, a widely used beta-blocker, inhibits the hydrolysis reaction of enzyme cholinesterase. Measurements of the difference in rate of hydrolysis rate between uninhibited and inhibited reactions allow the development of a kinetic method for its determination. Both systems, enzyme-substrate-chromogen and enzyme-substrate-chromogen-inhibitor, were characterized through biochemical kinetic parameters $\left(K_{\mathrm{M}}, 0.326-0.330 \mathrm{mmol} / \mathrm{L}\right.$; $\left.V_{\max }, 40.0-43.0 \mu \mathrm{mol} / \mathrm{Lmin}\right)$. The inhibition type was recognized as competitive and the inhibition constant, $K i$, was determined to be $22.60 \mu \mathrm{mol} / \mathrm{L}$. The detection and quantification limits were calculated as 0.004 and $0.0136 \mu \mathrm{mol} / \mathrm{L}$, respectively. Accuracy and precision of proposed methods were tested. The proposed method showed good sensitivity, selectivity, simplicity and rapidity, thus it is convenient for clinical applications.
\end{abstract}

Keywords: propranolol; cholinesterase inhibition; kinetic method; pharmaceuticals.

SCIENTIFIC PAPER

UDC 615.22:661.12:547

Hem. Ind. 66 (5) 677-684 (2012)

doi: 10.2298/HEMIND120128032S

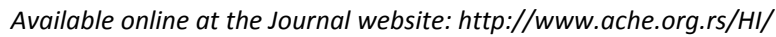

Propranolol (( $t$ )-isopropylamino-3-(1-naphthyloxy propan-2-ol) hydrochloride, PPH) is a widely prescribed drug in treatment of hypertension, angina pectoris, cardiac arrhythmia and hyperthyroidism. It belongs to a group of non-selective $\beta$-blockers, expressed with moderate intrinsic sympathetic mimetic activity. The relationship between the propranolol concentration in patients' blood and its pharmacological action is not always possible to establish, so that the dosage of the drug is determined by heart rate following and blood pressure measurements [1]. Regarding that fact, the determination of propranolol amounts in patients' blood is herein not of essential significance, but still, it is very important to monitor the quality of pharmacological preparations of propranolol hydrochloride, its content in effluents and finally in forensic samples.

A variety of methods was developed and validated for propranolol determination in samples of different origin. In the following review of the existing methods for propranolol determination, special attention will be devoted to the methods applied in pharmaceutical preparations and effluents (Table 1).

Numerous spectrophotometric methods give the opportunity to determine propranolol in pharmaceutical samples in various ranges, that can be generalized

Correspondence: V.P. Stankov-Jovanović, University of Niš, Faculty of Science and Mathematics, Department of Chemistry, Višegradska 33, 18000 Niš, Serbia.

E-mail: sjvesna@pmf.ni.ac.rs

Paper received: 28 January, 2012

Paper accepted: 15 March, 2012 as from 0 to $20 \mathrm{mmol} / \mathrm{L}$, while the other methods offer even more wide interval of determination (from 0 to $96.4 \mathrm{mmol} / \mathrm{L}$ [33]). Some of the methods are applied in nanomolar concentration intervals, though their low operational range or sensitivity is not really of substantial importance, having in mind the macroscopic nature of pharmaceutical or environmental samples. The main issue can be availability of the proposed assay, considering instruments and reagent, time spare and of course reliability. The high selectivity, short analysis time, simplicity are desirable as well as wide operational range.

Working on cholinesterase inhibition analytical studies $[35,36]$, and taking into consideration the presence of amino group in the molecule of propranolol (Figure 1) and literature data [37], the idea of developing an enzyme inhibition based assay emerged. The inhibiting effect of propranolol on serum cholinesterase was applied to a new kinetic enzyme method for its determination. Kinetic methods of analysis have the general advantage of combining high sensitivity, good selectivity with relatively simple, rapid procedures and inexpensive instruments, such as spectrophotometers. High specificity of the enzymatic reactions enabled usage pooled human serum as a source of cholinesterase. Modified Ellman's method [36] was applied for reaction rate monitoring. In that way, biochemical reaction and inhibition parameters were determined in common clinical biochemical laboratory conditions, without engagement of expensive instruments and reagents or using complex procedures. The proposed method was vali- 
Table 1. A review of the methods for propranolol determination in the pharmaceuticals

\begin{tabular}{|c|c|c|c|}
\hline Method & Range of determination, $\mu \mathrm{mol} / \mathrm{L}$ & Sample & Reference \\
\hline \multicolumn{4}{|c|}{ Spectrophotometric determinations } \\
\hline With $\mathrm{Ce}\left(\mathrm{SO}_{4}\right)_{2}$ & $0-16.90$ & Bulk drug, tablets & {$[2]$} \\
\hline With metavanadate & $0-13.52$ & Tablets & [3] \\
\hline Bromate/bromide mixture, methyl orange & $1.69-169.03$ & Tablets & {$[4]$} \\
\hline $\mathrm{Hg}(\mathrm{SCN})_{2}, \mathrm{Fe}^{3+}$ as indicator & $33.81-169.03$ & Bulk drug, tablets & {$[5]$} \\
\hline $\begin{array}{l}\text { Nitration of propranolol with uranyl nitrate and } \\
\text { thorium nitrate in } \mathrm{H}_{2} \mathrm{SO}_{4}\end{array}$ & $6.76-108.18$ & $\begin{array}{l}\text { Pure form, pharmaceutical } \\
\text { preparation }\end{array}$ & {$[6]$} \\
\hline $\begin{array}{l}\text { Propranolol oxidation by known excess of } \\
\mathrm{N} \text {-bromosuccinimide }\end{array}$ & $1.69-42.26$ & Dosage forms & [7] \\
\hline $\begin{array}{l}\text { Reaction of propranolol with sigma-acceptor iodine } \\
\text { and pi-acceptors }\end{array}$ & $13.52-405.68$ & $\begin{array}{l}\text { Pure form, pharmaceutical } \\
\text { formulation }\end{array}$ & [8] \\
\hline With diazotized 4-amino-3,5-dinitrobenzoic acid & $3.38-27.05$ & Tablets & [9] \\
\hline Excess of $\mathrm{N}$-bromosuccinimide + dye celestine blue & $0.676-16.903$ & Pharmaceutical formulation & {$[10]$} \\
\hline $\mathrm{KNO}_{3}+\mathrm{H}_{2} \mathrm{SO}_{4}(+$ alkaline $\mathrm{NaOH}$ and urea) & $1.08-405.68$ & Pharmaceuticals & [11] \\
\hline $\mathrm{NaNO}_{2}+\mathrm{K}_{2} \mathrm{SO}_{4}$ & $6.76-169.03$ & Dosage forms & [12] \\
\hline $\begin{array}{l}\text { Dissolution in isopropanol, addition of } \mathrm{Ag}_{2} \mathrm{O}+ \\
10 \% \mathrm{CH}_{3} \mathrm{CHO} \text { and } 10 \% \text { chloranil }\end{array}$ & $16.90-202.84$ & Bulk tablets & [13] \\
\hline With brom thymol blue & $3.00-25.00$ & Bulk tablets & [14] \\
\hline With 2,4 dinitro-1-fluorobenzene & $16.90-101.42$ & Tablets & [15] \\
\hline Complex formation with $\mathrm{Cu}(\mathrm{II})$ and $\mathrm{Co}(\mathrm{II})$ & 20-20000 & Dosage forms & {$[16]$} \\
\hline \multicolumn{4}{|c|}{ Other methods } \\
\hline Differential pulse polarography & $0.50-50.00$ & Tablets & [17] \\
\hline Cyclic voltametry and pulse voltametry & $1-20$ & Spiked water samples & [18] \\
\hline Phosphorimetric & $0-1.69$ & Pharmaceutical preparations & [19] \\
\hline AAS (chelation with $\mathrm{Cu}(\mathrm{II})$ ion) & $0-135.23$ & Pharmaceutical preparations & {$[20]$} \\
\hline Indirect AAS method & $4.54-346.98$ & Water solutions, tablets & [21] \\
\hline Spectrofluorimetry & $0.08-0.68$ & Tablets, injections & {$[22]$} \\
\hline Spectrofluorimetry & $0.023-0.771$ & Pharmaceutical formulations & [23] \\
\hline Spectrofluorimetry & $0.077-3.856$ & $\begin{array}{l}\text { Urine, pharmaceutical } \\
\text { preparations }\end{array}$ & {$[24]$} \\
\hline SIA with fluorescence detection & $0-15.423$ & Tablets & {$[25]$} \\
\hline Chemiluminometry & $77.115-578.363$ & Pharmaceutical preparations & [26] \\
\hline FIA with fluorescence detection & $0-0.001$ & $\begin{array}{l}\text { Pharmaceutical preparations, } \\
\text { urine }\end{array}$ & {$[27]$} \\
\hline FIA with chemiluminiscence detection & $3.855-77.100$ & Pharmaceutical formulations & [28] \\
\hline FIA with chemiluminiscence detection & $3.855-67.462$ & Pharmaceutical preparations & [29] \\
\hline Kinetic-potentiometric & 100-1000 & Commercial formulations & [30] \\
\hline $\begin{array}{l}\text { Miccelar stabilized room temperature } \\
\text { phosphorescence }\end{array}$ & $0.096-1.536$ & Commercial formulations, urine & [31] \\
\hline Potentiometric sensors & $0.1-10000$ & Dosage forms & {$[32]$} \\
\hline LC & $3.856-96.400$ & Pharmaceutical formulations & [33] \\
\hline SPE-LC-ESI/MS & $0.00068-0.02197$ & Hospital effluent wastewaters & {$[34]$} \\
\hline
\end{tabular}

dated in accordance with modern analytical demands (selectivity, sensitivity, linearity, accuracy, precision etc.).

\section{EXPERIMENTAL}

All used chemicals and reagents were p.a. grade. Propranolol hydrochloride (PPH, purity $>99 \%$ ) was kindly provided by Galenika AD, Belgrade; stock solution was of $10 \mathrm{mg} / \mathrm{mL}$ in deionized water. Working solutions were prepared daily, by dilution of the stock solution. Buthyrylthiocholine iodide (BUTC, purity > 99\%), 5,5'-dithiobis(2-nitrobenzoic acid) (DTNB) were purchased from Sigma, Germany. BUTC stock solution was of $133.33 \mathrm{mmol} / \mathrm{L}$. DTNB stock solution was prepared by 
dissolving the exact weighted mass $(0.0792 \mathrm{~g})$ in $5 \mathrm{~mL}$ of phosphate buffer $\mathrm{pH} 7.4$, followed by addition of 60 $\mathrm{mg}$ of $\mathrm{NaHCO}_{3}$, and dilution to $10 \mathrm{~mL}$ in the volumetric flask. $\mathrm{NaHCO}_{3}, \mathrm{KH}_{2} \mathrm{PO}_{4}, \mathrm{Na}_{2} \mathrm{HPO}_{4}$, used for the buffers preparation, were from Merck, Germany.

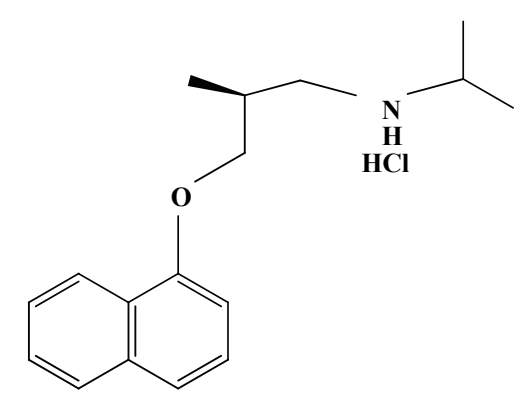

Figure 1. Structural formula of propranolol hydrochloride.

For solutions preparation and for final dishes washing, deionized water (conductivity $<1 \mu \mathrm{S}$, MicroMed high purity water system, TKA Wasseraufbereitungssysteme $\mathrm{GmbH}$ ) was used.

All concentrations described here are the initial concentrations in the reaction mixture at time zero after mixing.

A Konelab 20 analyzer (Thermo Scientific), with flow thermostated cells, length $7 \mathrm{~mm}, \lambda=405 \mathrm{~nm}$ was used for spectrophotometric measurements. The main advantage of the Konelab 20 analyzer is its use of very small volumes of reagents (the volume of the measuring probe is $200 \mu \mathrm{L}$ ), though the possibility of performing about 40 analyses per hour is not negligible either.

Ten healthy volunteers (18-65 years old from both sexes) donated their blood with written consent, which was used for serum preparation in the Pirot General Hospital. Each of the volunteers had neither recent nor past history of significant medical disorder, as well as drug, cigarette or alcohol abuse. For at least a month before blood donation, none of the volunteers had been taking any medication. A $5 \mathrm{~mL}$ blood sample was collected from each donator in a vacutainer tube, centrifuged for $10 \mathrm{~min}$ at $3000 \mathrm{rpm}$, after which the serum supernatants were collected, mixed and used for the enzyme assay. The hydrolysis reaction of butyrylthiocholine to thiocholine is catalyzed by serum cholinesterase; the product reacts with DTNB forming colored compound (5-thio-2-nitrobenzoic acid); the reaction rate is determined from the increase of color, measured at $405 \mathrm{~nm}$, in 6 cycles of $28 \mathrm{~s}$ and thermostated at $310 \mathrm{~K}$.

Solutions of propranolol $(10 \mu \mathrm{L})$ were mixed with serum diluted with the phosphate buffer in ratio 1:9, $\mathrm{v} / \mathrm{v}(10 \mu \mathrm{L})$, the phosphate buffer solution $(160 \mu \mathrm{L})$ and preincubated $10 \mathrm{~min}$ (at $310 \mathrm{~K}$ ); DTNB solution $(10 \mu \mathrm{L}$ ) was added and left for $60 \mathrm{~s}$; substrate solution (BUTC,
$10 \mu \mathrm{L}$ ) was added. The same procedure was applied for analysis of samples. The obtained kinetic data were interpreted by tangent method. Each kinetic result is the average of five determinations.

Twenty tablets of every pharmaceutical preparation was taken and ground into a fine powder. Mass of the powder equivalent to $100 \mathrm{mg}$ of $\mathrm{PPH}$ was exactly weighed and transferred into a $100 \mathrm{~mL}$ calibrated flask. About $60 \mathrm{ml}$ of water was added and the content was vigorously shaken. The contents were filtered using a quantitative filter paper into the $100 \mathrm{~mL}$ volumetric flask and diluted to the mark. An appropriate volume of the stock solution was used for analysis.

\section{RESULTS AND DISCUSSION}

The main parameters affecting the performance of the proposed method were studied to determine the optimal working configuration. These parameters were optimized by the invariant method, i.e., each parameter was optimized by setting the other parameters to be constant. To determine the kinetic biochemical parameters, the dependence of reaction rate on substrate (butyrylthiocholine) concentration was estimated for the range $0.208-6.650 \mathrm{mmol} / \mathrm{L}$. The methods of Lineweaver-Burk, Eadie-Hofstee and Hanes linearization, resulted with the similar values for Michaelis-Menten's constant $(0.330,0.305$ and $0.326 \mathrm{mmol} / \mathrm{L}$, respectively) and also for $V_{\max }(42.29,40.00$ and $42.38 \mu \mathrm{mol} / \mathrm{L}$, respectively). The obtained kinetic data enable conclusion that the PPH and serum cholinesterase interact in the competitive inhibition manner. Once the mechanism of inhibition was established, the inhibition constant was calculated from the function of the inhibition reaction rate depending of different PPH concentrations. Dixon's method was applied for inhibition constant determination, which was found to be $2.71 \mu \mathrm{mol} / \mathrm{L}$.

Different PPH concentrations affect relative enzyme activity of the serum cholinesterase in the manner shown in Figure 2. At PPH concentration of 169.03 $\mu \mathrm{mol} / \mathrm{L}$, the enzyme is almost completely inhibited. The $I C_{50}$ value was determined as $22.60 \mu \mathrm{mol} / \mathrm{L}$. The interval of relative enzyme activity higher than $48.35 \%$ was applied for the development of method for PPH determination.

The dependences of reaction rates on $\mathrm{pH}$ for reaction without/with inhibitor are shown in Figure 3. The $\mathrm{pH} 7.6$ was chosen as optimal, because that $\mathrm{pH}$ value gave the greatest difference for basic and inhibitor reaction rates.

Six substrate (butyrylthiocholine iodide) concentrations $(0.208,0.416,0.833,1.667,3.334$ and 6.665 $\mathrm{mmol} / \mathrm{L}$ ) were used for the estimation of the reaction rates for reaction without/with different PPH concentrations (Figure 4). The substrate concentration 1.667 $\mathrm{mmol} / \mathrm{L}$ was chosen as optimal, because that value 


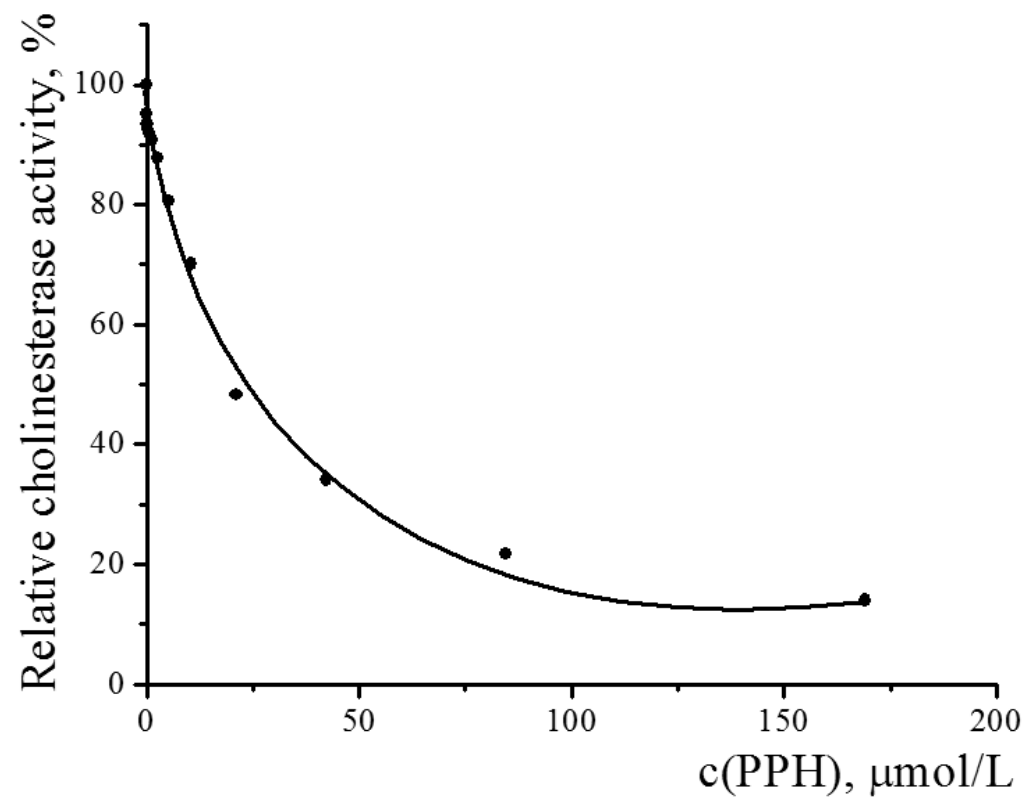

Figure 2. Function of relative activity of serum cholinesterase on concentration of propranolol (PPH).

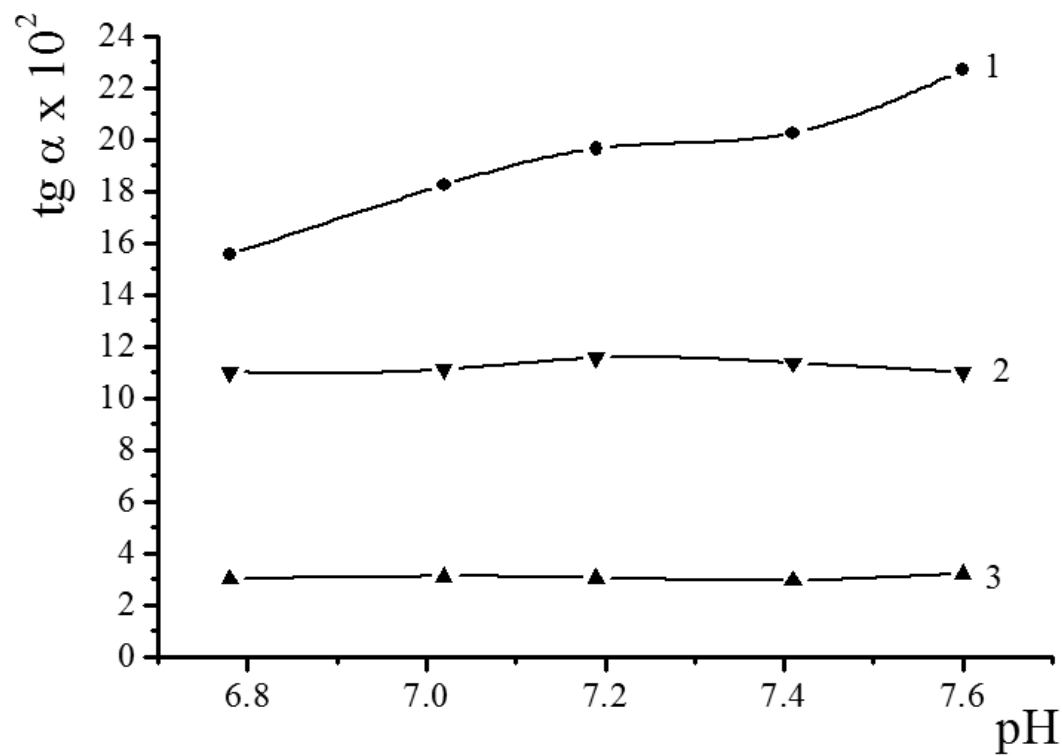

Figure 3. The dependence of the reaction rate in absence of $P P H(1)$ and in presence of $P P H(2,3)$ on $p H$. Conditions: $c(B U T C)=1.667 \mathrm{mmol} / \mathrm{L} ; c($ phosphate buffer $)=100 \mathrm{mmol} / \mathrm{L} ; 2-c(P P H)=2.637 \mu \mathrm{mol} / \mathrm{L} ; 3-c(P P H)=21.129 \mu \mathrm{mol} / \mathrm{L}) ; T=310 \mathrm{~K}$.

gave the maximal difference in the basic and inhibitor reaction rates.

The differential variant of tangent method [38] was applied for the construction of calibration graph, under

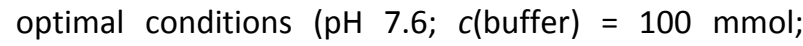
$c($ butyrylthioholine iodide $)=1.667 \mathrm{mmol} / \mathrm{L} ; T=310 \mathrm{~K})$. The linear relationship between the slope $(\tan \alpha)$ and $\mathrm{PPH}$ concentrations in the range 0.082-21.120 $\mu \mathrm{mol} / \mathrm{L}$ (in probe) was established. The equation used for the calibaration graph was:

$\tan \alpha \times 100=(21.2853 \pm 0.0871)-(0.4937 \pm 0.0107) c$

where $c$ is expressed in $\mu \mathrm{mol} / \mathrm{L}$ and $R=-0.99836$.
The limit of detection (LOD) and limit of quantification (LOQ) were calculated applying formulas $3 S D_{\mathrm{B}} / \mathrm{m}$ and $10 S D_{\mathrm{B}} / \mathrm{m}$ respectively (where $S D_{\mathrm{B}}$ is standard deviation of the blank signal and $m$ has a definite value when the intercept of the calibration graph is zero or virtually zero [39] and they were 0.004 and 0.0136 $\mu \mathrm{mol} / \mathrm{L}$, respectively. Five replicate experiments for the blank and three concentrations of PPH were conducted for precision and accuracy estimation of the proposed method and the results are shown in Table 2.

By applying the calibration graph, it is possible to determine propranolol from different samples in the range $1.65-422.40 \mu \mathrm{mol} / \mathrm{L}$. 


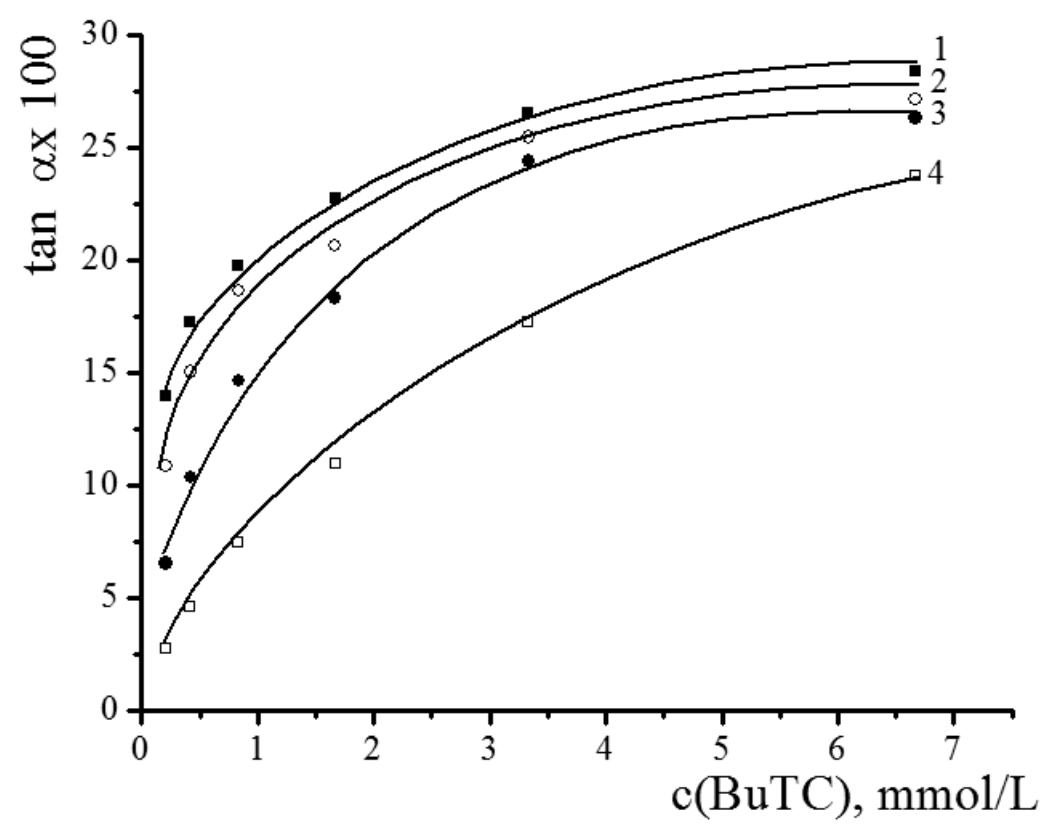

Figure 4. The dependence of the reaction rate without (1) and with PPH at different concentrations (2-1.318, 3-5.282 and 4-21.129 $\mu \mathrm{mol} / \mathrm{L}$ ) on buthyry/thiocholine concentration; $c$ (buffer) $=100 \mathrm{mmol} / \mathrm{L}, \mathrm{pH} 7.6 ; T=310 \mathrm{~K}$.

Table 2. Precision (presented as RSD \%) and accuracy (presented as Recovery \%) of the proposed method; the concentrations present averages of five determinations \pm standard deviation ( $X \pm S D$ )

\begin{tabular}{|c|c|c|c|c|c|}
\hline $\begin{array}{l}\text { c(PPH) in probe } \\
\text { (measured), } \mu \mathrm{mol} / \mathrm{L}\end{array}$ & $\begin{array}{c}c(\mathrm{PPH}) \text { in the initial } \\
\text { solution(measured), } \mu \mathrm{mol} / \mathrm{L}\end{array}$ & $\begin{array}{c}c(\mathrm{PPH}) \text { in probe (found) } \\
\mu \mathrm{mol} / \mathrm{L}, \bar{x} \pm \mathrm{SD}\end{array}$ & $\begin{array}{l}c(\mathrm{PPH}) \text { in the initial solution } \\
\text { (found), } \mathrm{mmol} / \mathrm{L}, x \pm \mathrm{SD}\end{array}$ & $R S D / \%$ & Recovery, \% \\
\hline 0.659 & 13.180 & $0.666 \pm 0.023$ & $13.328 \pm 0.462$ & 3.47 & 101.06 \\
\hline 2.637 & 52.740 & $2.668 \pm 0.083$ & $53.352 \pm 1.655$ & 3.10 & 101.17 \\
\hline 10.565 & 211.300 & $10.697 \pm 0.15$ & $211.300 \pm 3.093$ & 1.45 & 101.46 \\
\hline
\end{tabular}

In order to examine the impact of possible interferences, the influence of the most common filling substances (calciumcarboxymethylcellulose, carmine, gelatin, glycerol, lactose, magnesium carbonate, magnesium stearate, methylhydroxypropylcellulose and $\mathrm{TiO}_{2}$ ) was tested on the inhibitor reaction rate. The potential interfering substances were taken in excess and prepared in the same way as pharmaceutical samples. Regarding the 2SD criteria [40] at constant propranolol concentration in the probe of $10.56 \mu \mathrm{mol} / \mathrm{L}$, none of the potential interferences showed measurable influence on the inhibitor reaction rate, in the double ratio that exists in pharmaceutical formulations.
The proposed method was applied for PPH determination in tablets of different origin. Results were validated by standard addition method (Table 3 ).

\section{CONCLUSION}

The known fact that propranolol inhibits human serum cholinesterase activity was confirmed and kinetic biochemical parameters were established. On that basis, the competitive type of inhibition was proposed, which can be justified by the existence of charge depolarization in the propranolol hydrochloride molecule, which can be very well fitted in the active site of the enzyme very similar to the acylcholine esters. Con-

Table 3. Precision (RSD) and accuracy (standard addition method) test of PPH determination in tablets. Results are expressed as average of five replicate $(x \pm S D)$ experiments for different $P P H$ concentrations

\begin{tabular}{|c|c|c|c|c|c|}
\hline$\underline{\text { Sample }}$ & $c(\mathrm{PPH})^{\mathrm{a}}, \mathrm{mg} /$ tablet & Found $c(\mathrm{PPH})^{\mathrm{b}}, \mathrm{mg} /$ tablet & $R S D / \%$ & Found $\mathrm{c}(\mathrm{PPH})^{\mathrm{c}}, \mathrm{mg} /$ tablet & Mean value of recovery, $\%$ \\
\hline Propranolol tablets & 40 & $39.89 \pm 0.60$ & 1.50 & $40.21 \pm 0.56$ & 100.15 \\
\hline Inderal tablets & 10 & $9.96 \pm 0.14$ & 1.16 & $9.98 \pm 0.11$ & 99.85 \\
\hline Inderal tablets & 40 & $39.77 \pm 0.60$ & 1.52 & $39.86 \pm 1.17$ & 99.64 \\
\hline Inderal tablets & 80 & $79.75 \pm 1.25$ & 1.57 & $79.87 \pm 0.88$ & 99.84 \\
\hline
\end{tabular}

\footnotetext{
a Labeled by manufacturer; ${ }^{b}$ calibration graph; ${ }^{c}$ standard addition method
} 
firming and characterizing the inhibition enabled the possibility of development of a new enzymatic kinetic assay for propranolol determination.

Methods for quantification of propranolol are crucial in determining the quality of pharmacological preparations. The proposed method, with its broad determination interval, excellent sensitivity, simplicity, reproducibility, precision, accuracy and selectivity, satisfies all the requirements for practical application. In addition, the equipment used for its implementation is available to any clinical laboratory, which greatly contributes to the availability of the method.

\section{Ackowledgement}

This research was supported by the grant No. 172051 from the Ministry of Education, Science and Technological Development of the Republic of Serbia. The authors are grateful for the financial support provided by the Ministry.

\section{REFERENCES}

[1] Harison's Principles of Internal Medicine, Part four: Clinical Pharmacology, $15^{\text {th }}$ ed., CD-ROM, McGraw-Hill Companies, Inc., 2004.

[2] K. Basavaiah, U. Chandrashekar, H.C. Prameela, Cerimetric determination of propranolol in bulk drug form and in tablets, Turk. J. Chem. 27 (2003) 591-599.

[3] K. Basavaiah, U. Chandrashekar, H.C. Prameela, Indirect titrimetric and spectrophotometric determination of propranolol hydrochloride using sodium metavanadate, Bulg. Chem. Ind. 74 (2003) 79-84.

[4] K. Basavaiah, U. Chandrashekar, H.C. Prameela, P. Nagegowda, Quantitative determination of propranolol with bromate and methyl orange, Acta Ciencia Indica Chem. 29 (2003) 25-30.

[5] K. Basavaiah, U. Chandrashekar, V.S. Charan, Application of precipitation and complexation reactions for the analysis of propranolol hydrochloride, Indian J. Pharm. Sci. 65 (2003) 161-166.

[6] A.G. Sajjan, J. Seetharamappa, S.P. Masti, Spectrophotometric determination of propranolol hydrochloride in pharmaceutical preparations, Indian J. Pharm. Sci. 64 (2002) 68-70.

[7] B.G. Gowda, J. Seetharamappa, M.B. Melwanki, Indirect spectrophotometric determination of propranolol hydrochloride and piroxicam in pure and pharmaceutical formulations, Anal. Sci. 18 (2002) 671-674.

[8] H. Salem, Spectrophotometric determination of $\beta$-adrenergic blocking agents in pharmaceutical formulations, J. Pharmaceut. Biomed. 29 (2002) 527-538.

[9] O.S. Idowu, O.A. Adegoke, A.A. Olaniyi, Colorimetric assay of propranolol tablets by derivatization: Novel application of diazotized 4-amino-3,5-dinitrobenzoic acid (ADBA), J. AOAC Int. 87 (2004) 573-578.

[10] C.S.P. Sastry, K.R. Srinivas, K.M. Prasad, M. Krishna, Spectrophotometric determination of drugs in pharma- ceutical formulations with $\mathrm{N}$-bromosuccinimide and celestine blue, Mikrochim. Acta 122 (1996) 77-86.

[11] N.M. Sanghavi, J.J. Vyas, Use of nitrating agent in the colorimetric determination of drugs - part I, Indian Drugs 29 (1992) 317-320.

[12] K. Raman, Y.K. Agrawal, Colorimetric determination of propranolol hydrochloride. Indian J. Pharm. Sci. 51 (1989) 144-146.

[13] D.M. Shingbal, A.S. Khandeparkar, Colorimetric method for the determination of propranolol hydrochloride from pharmaceutical preparations, Indian Drugs $\mathbf{2 4}$ (1987) 365-366.

[14] D. Radulović, M.S. Jovanović, Lj. Živanović, Spectrophotometric determination of propranolol hydrochloride in tablets as bromthymol blue ion pairs, Pharmazie 41 (1986) 434-439.

[15] D.M. Shingbal, J.S. Prabhudesai, Spectrophotometric estimation of propranolol hydrochloride, Indian Drugs 21 (1984) 304-305.

[16] E.A. Golcu, C. Yucesoy, S. Serin, Spectrophotometric determination of some beta-blockers in dosage forms based on complex formation with $\mathrm{Cu}(\mathrm{II})$ and $\mathrm{Co}(\mathrm{II})$, Farmaco 59 (2004) 487-492.

[17] M.A. El-Ries, M.M. Abou-Sekkina, A.A. Wassel, Polarographic determination of propranolol in pharmaceutical formulation, J. Pharmaceut. Biomed. 30 (2002) 837$-842$.

[18] A. Ambrosi, R. Antiochia, L. Campanella, R. Dragone, I. Lavagnini, Electrochemical determination of pharmaceuticals in spiked water samples, J. Hazard. Mater. 122 (2005) 219-225.

[19] B. Canabate-Diaz, B.C. Cruces, A.S. Carretero, A.G. Fernandez, Simple determination of propranolol in pharmaceutical pr eparations by heavy atom induced room temperature phosphorescence, J. Pharmaceut. Biomed. 30 (2002) 987-992.

[20] M.A. El-Ries, F.M. Abou Attia, S.A. Ibrahim, AAS and spectrophotometric determination of propranolol $\mathrm{HCl}$ and metoprolol tartarate, J. Pharmaceut. Biomed. 24 (2000) 179-187.

[21] S. Khalil, N. Borham, Indirect atomic absorption spectrometric determination of pindolol, propranolol and levamisole hydrochlorides based on formation of ionassociates with ammonium reineckate and sodium cobaltinitrite, J. Pharmaceut. Biomed. 22 (2000) 235-240.

[22] M. Gajewska, G. Glass, J. Kostelecki, Spectrofluorimetric determination of propranolol and atenolol, Acta Pol. Pharm. 49 (1992) 1-4.

[23] J.A.M. Pulgarin, A.A. Molina, P.F. Lopez, Simultaneous determination of atenolol, propranolol, dipyridamole and amiloride by means of non-linear variable-angle synchronous fuorescence spectrometry, Anal. Chim. Acta 370 (1998) 9-18.

[24] T.P. Ruiz, C. Martynez-Lozano, V. Tomas, J. Carpena, Simultaneous determination of propranolol and pindolol by synchronous spectrofluorimetry, Talanta 45 (1998) 969-976.

[25] S.A. Motz, J. Klimundov, U.F. Schaefer, S. Balbach, T. Eichinger, P. Solich, C.M. Lehr, Automated measurement 
of permeation and dissolution of propranolol $\mathrm{HCl}$ tablets using sequential injection analysis, Anal. Chim. Acta $\mathbf{5 8 1}$ (2006) 174-180.

[26] K.L. Marques, J.L.M. Santos, J.L.F.C. Lima, Chemiluminometric determination of propranolol in an automated multicommutated flow system, J. Pharmaceut. Biomed. 39 (2005) 886-891.

[27] J.F. Fernandez-Sanchez, A.S. Carretero, C. Cruces-Blanco, A. Fernandez-Gutierrez, A sensitive fluorescence optosensor for analysing propranolol in pharmaceutical preparations and a test for its control in urine in sport, J. Pharmaceut. Biomed. 31 (2003) 859-865.

[28] G.Z. Tsogas, D.V. Stergiou, A.G. Vlessidis, N.P. Evmiridis, Development of a sensitive flow injection-chemiluminescence detection method for the indirect determination of propranolol, Anal. Chim. Acta 541 (2005) 151$-157$.

[29] A. Townshend, J.A. Murillo Pulgarin, M.T. Alanon Pardo, Flow injection-chemiluminescence determination of propranolol in pharmaceutical preparations, Anal. Chim. Acta 488 (2003) 81-88.

[30] E. Athanasiou-Malaki, M.A. Koupparis, T.P. Hadjiioannou, Kinetic determination of primary and secondary amines using a fluoride-selective electrode and based on their reaction with 1-fluoro-2,4-dinitrobenzene, Anal. Chem. 61 (1989) 1358-1363.

[31] J.A.M. Pulgarin, A.A. Molina, P.F. Lopez, M.T.A. Pardo, Fast determination of propranolol in urine and pharmaceutical preparations by stopped-flow and micellar-stabilized room-temperature phosphorescence: validation of the method, Anal. Biochem. 312 (2003) 167-174.

[32] S.S.M. Hassan, M.M. Abou-Sekkina, M.A. El-Ries, A.A. Wassel, Polymeric matrix membrane sensors for sen- sitive potentiometric determination of some $\beta$-blockers in pharmaceutical preparations, J. Pharmaceut. Biomed. 32 (2003) 175-180.

[33] M. Gil-Agusty, S. Carda-Broch, M.E. Capella-Peiro, J. Esteve-Romero, Micellar liquid chromatographic determination of five antianginals in pharmaceuticals, J. Pharmaceut. Biomed. 41 (2006) 1235-1242.

[34] M.J. Gomez, M. Petrović, A.R. Fernandez-Alba, D. Barcelo, Determination of pharmaceuticals of various therapeutic classes by solid-phase extraction and liquid chromatography-tandem mass spectrometry analysis in hospital effluent wastewaters, J. Chromatogr., A 1114 (2006) 224-233.

[35] V.P. Stankov-Jovanović, S.D. Nikolić-Mandić, Lj.M. Mandić, V.D. Mitić, Cholinesterase inhibition based determination of pancuronium bromide in biological samples, Anal. Bioanal. Chem. 385 (2006) 1462-1469.

[36] V.P. Stankov-Jovanović, S.D. Nikolić-Mandić, Lj.M. Mandić, V.D. Mitić, A modification of the kinetic determination of pancuronium bromide based on its inhibitory effect on cholinesterase, J. Clin. Lab. Anal. 21 (2007) 124-131.

[37] M. Whittaker, J.J. Britten, R.J. Wicks, Inhibition of the plasma cholinesterase variants by propranolol, Brit. J. Anaesth. 53 (1981) 511-516.

[38] K.B. Yatsimirskii, Kinethic Methods of Analysis, Khimiya, Moskva, 1967, pp. 55-56.

[39] J.C. Miller, J.N. Miller, Statistics for Analytical Chemistry. Willey. New York, 1984.

[40] G.F. Kirkbright, Development and publication of new spectro-photometric methods of analysis, Talanta 13 (1966) 1-14. 


\section{IZVOD}

\section{ENZIMSKA KINETIČKA METODA ZA ODREĐIVANJE PROPRANOLOL-HIDROHLORIDA U FARMACEUTSKIM PREPARATIMA ZASNOVANA NA NJEGOVOM INHIBITORSKOM DELOVANJU NA HOLINESTERAZU}

Vesna P. Stankov-Jovanović ${ }^{1}$, Violeta D. Mitić ${ }^{1}$, Marija D. Ilić ${ }^{1}$, Ljuba M. Mandić ${ }^{2}$ Snežana D. Nikolić-Mandić ${ }^{2}$

${ }^{1}$ Univerzitet u Nišu, Prirodno-matematički fakultet, Niš, Srbija

${ }^{2}$ Univerzitet u Beogradu, Hemijski fakultet, Beograd, Srbija

(Naučni rad)

Za propranolol, često propisivani neselektivni beta blokator, utvrđeno je da inhibira reakciju enzimske hidrolize butiriltioholin-jodida, koja je katalizovana serumskom holinesterazom. Merenjem razlike u brzini osnovne i inhibitorske reakcije hidrolize u prisustvu propranolola kao inhibitora, moguće je razviti kinetičku metodu za određivanje propranolola. Oba sistema, enzim-supstrat-hromogen kao i enzim-supstrat-hromogen-inhibitor okarakterisani su biohemijskim kinetičkim parametrima $\left(K_{\mathrm{M}}, 0,326-0,330 \mathrm{mmol} / \mathrm{L} ; V_{\max }, 40-42,99 \mu \mathrm{mol} / \mathrm{L} \mathrm{min}\right)$, inhibicija je definisana kao kompetitivna i određena je konstanta inhibicije 22,60 $\mu \mathrm{mol} / \mathrm{L}$. Da bi se u potpunosti iskoristile sve mogućnosti predložene metode u pogledu osetljivosti, tačnosti, preciznosti i selektivnosti, optimizovani su reakcioni uslovi. Konstruisana je kalibraciona prava, izračunata odgovarajuća jednačina i određeni granica detekcije i kvantifikacije, i to 0,004 i 0,0136 $\mu \mathrm{mol} / \mathrm{L}$, redom. Tačnost i preciznost predložene metode su ispitane za tri koncentracije propranolola $u$ oblasti kalibracione prave $(0,082-21,120 \mu \mathrm{mol} / \mathrm{L}) \mathrm{u}$ pet ponavljanja. Takođe, ispitan je uticaj većeg broja supstanci koje se mogu naći u uzorku na brzinu reakcije. Optimizovana metoda je primenjena za određivanje propranolola u farmaceutskim preparatima. Tačnost predložene metode je ispitana primenom metode standardnog dodatka. Predložena metoda ima dobru osetljivost, selektivnost, jednostavna je i brza, i nadasve lako dostupna, i na taj način primenljiva u velikom broju laboratorija.
Ključne reči: Propranolol • Holinesteraza - Kinetička metoda • Farmaceutski preparati 